\title{
Key Performance Indicators to Assess and Reverse the Negative Impacts of SECA Policies for Ro-Ro Shipping
}

Thalis Zis

Postdoctoral Research Associate Technical University of Denmark Department of Management

Engineering Denmark

Harilaos N. Psaraftis

Professor Technical University of Denmark Department of Management Engineering Denmark

The $0.1 \%$ sulphur limit within Sulphur Emission Control Areas (SECA) has made compulsory the use of either pricier ultra-low sulphur fuel, or the installation of abatement technologies that require significant capital investments. Due to the unexpectedly low fuel prices, Ro-Ro operators have been able to cope with the new sulphur limits, but recent research has shown that if fuel prices increase some Ro-Ro services may face the risk of closure. This paper proposes three key performance indicators (KPIs) to enable the asssessment of the impact of SECAs on Ro-Ro shipping. The KPIs are used on a set of case studies for services of a leading European Ro-Ro operator, and allow benchmarking of a series of operational and policy measures that aim to reverse the negative impacts of SECAs. The operational measures consider speed reduction, new sailing frequency, fleet reconfiguration, as well as investments in abatement technologies. Policy measures include the options of either subsidizing shippers or ship operators, or alternatively introducing new taxes on landbased options. The KPIs can be useful to ship operators seeking to improve the resilience of their network, as well as to regulatory bodies designing new environmental policies and understanding any negative implications these may have on ship operators

Keywords:Modal shifts, Green Logistics, Ro-Ro shipping.

\section{INTRODUCTION}

Maritime transport moves approximately $80 \%$ of the total worldwide cargo [1]. Economies of scale and technological improvements in ship design and engine efficiency have constituted maritime shipping as the most fuel efficient mode of freight transport. Ship operators have seen newer regulations in recent years that have increased their operating costs. This was particularly threatening for the short sea shipping (SSS) sector that competes heavily with other transportation modes. Defining the SSS is a debated subject and this paper uses the definition of Bjornland (1993) as the transportation of people and goods through without crossing an ocean [2].

There have been many studies in the literature claiming that shipping is the most environmentally friendly mode of transport. This holds some truth with regards to carbon emissions as shipping is responsible for $2.2 \%$ of the global $\mathrm{CO}_{2}$ emissions when the whole transportation sector is estimated at $22 \%$ [3]. This is not the case when it comes to other pollutant species, where the relative contribution of shipping is increasing. Particularly for $\mathrm{SO}_{\mathrm{x}}$ emissions estimated between 5 and $8 \%$ of the global contribution [4] and responsible for $\mathrm{NO}_{\mathrm{x}}$ and $\mathrm{PM}$ emissions. To address the issue of $\mathrm{SO}_{\mathrm{x}}$

Received: January 2018, Accepted: March 2018

Correspondence to:Dr. Thalis Zis, Postdoctoral Researcher Department of Management Engineering, Bygning 424, Produktionstorvet, 2800 Kgs. Lyngby, Denmark E-mail: tzis@dtu.dk

doi:10.5937/fmet1803347Z

(C) Faculty of Mechanical Engineering, Belgrade. All rights reserved from shipping, the revised MARPOL Annex VI has set maximum limits on the allowable sulphur content inbunker fuels, differentiating between activity in and out of SECAs (where stricter limits apply).

In order to comply with the regulation limits, ship operators have to either use pricier ultra low-sulphur fuels (for example Marine Gas Oil - MGO, or hybrid low-sulphur HFO), LNG, or invest in other abatement technologies such as scrubber systems which require significant capital investment costs. Low sulphur fuel is in general offering more flexibility to ship operators as they can continue operation by switching fuel when sailing in regulated waters. LNG contains no sulphur and offers a permanent solution to the $\mathrm{SO}_{\mathrm{x}}$ regulations. LNG is also currently less expensive than bunker fuel; however, there are barriers to its further implementation. One concern is the so-called methane slip, whereby methane can be released in the atmo-sphere. Methane has much higher green-housing poten-tial compared to carbon dioxide. There is also a limited amount of bunkering ports for LNG. The total capital investment costs for an LNG retrofit of a Ro-Ro vessel can reach $10.5 \mathrm{M} €[5]$. On scrubber systems, recent work has shown that due to the to the lower fuel prices, investments would see an increased payback period [6].

All compliance options will either increase the operating costs due to the use of pricier fuel, or will require significant capital investments for a permanent solution. The increased costs would prompt ship operators to increase freight rates in response that could lead to shifts towards unaffected transportation modes. The freight rates of Ro-Ro operators are passing any 
fluctuations in fuel prices via the bunker adjustment factor (BAF). Each European operator is required by law to have its own method of calculating the BAF, and the majority is now including the price differential between MGO and HFO in the calculation. January 2015 was a turning point as the regulation enforced the use of ultra-low sulfur fuel with a content of a maximum of $0.1 \% \mathrm{~S}$ within SECAs. Prior to this point, there were widespread concerns that the new limit would lead to closures of services and result in modal backshifts towards road and rail modes.

However, fuel prices were unexpectedly low in 2015 to the point that MGO was actually cheaper than what HFO $1 \%$ was before the new limits, something that masked the negative effects of the regulation. $\mathrm{Zis}$ et al. (2017) showed that if the fuel prices would revert to previous high levels, the maritime modes would lose significant market shares that could threaten their service [7]. Had the regulated limits not been imposed, the maritime modes would have attracted even higher transport volumes, achieving higher profits.

Due to high competition, an increase in fuel prices may affect significantly the SSS sector and lead to significant loss of market share to competing landbased modes. The profitability of a service will therefore be affected by both an increase in operating and/or capital costs, as well as a decrease in transported volumes. It is therefore imperative for operators to plan ahead with the examination of potential operating measures that can help the sector cope in such an event. There is an additional need for regulators to examine potential policies that can mitigate and reverse these modal backshifts.

This paper utilizes an established methodological framework that allows the estimation of modal shifts for cargo flows as a consequence of the lower sulfur limits within SECAs. The paper then presents a set of measures that the ship operator can deploy to cope with the negative effects of the regulation. The measures are compared in terms of their efficacy with the development of key performance indicators (KPI) for different fuel price scenarios. For all scenarios, data from a leading European Ro-Ro operator are used and the measures are examined for their effects on this operator. The paper finally considers the total annual costs for a full reversal of the effects of the regulation if a policy body would refund the additional costs to shippers. The paper concludes with a discussion on the role of fuel prices on the profitability of a Ro-Ro service and with a recommendation for further research on upcoming regulation.

\section{METHODOLOGY}

In order to understand the implications of changes in the affected services, it is necessary to estimate modal shifts. This section summarises this process.

\subsection{Data Collection}

Modal split models are used to estimate the probability of selecting a particular mode among different available options, given a specific transport demand between the origin and destination. These discrete choice models can be useful in estimating shifts as a consequence of any changes in the available options.Changes might involved a higher/lower transport cost for an option, a different travel time, or even the removal or addition of a transport link. For all applications of discrete choice models, the required data involve information on the market share of each of the available options (e.g. how many users select each option) that serves as the baseline for the model's calibration. In transportation the majority of discrete choice models are focusing on passenger or driver behavior with considerably less applications concerning freight transport. This can be attributed to the fact that when decision makers are individuals, more information is taken into consideration (cost, time, number of transit changes, comfort, weather, etc.) whereas shippers are primarily concerned with cost, time, and reliability. In addition, the cargo value is also a factor as it may be of a perishable nature thus increasing the need for a quick transportation.

\subsection{The modal split model}

This work is using a two-stage logit model that was developed and calibrated for a set of Ro-Ro routes in the North and Baltic Sea. More information on the model is provided in the literature [7]. The model calculates the probability of choosing a mode following changes in any of the available options. The generalized cost of transport is representing the disutility of each alternative as shown in equation 1 .

$$
G C_{i}=T C_{i}+\frac{C V \cdot r}{8760} \cdot T T_{i}
$$

where $T C_{i}(€ /$ lanemeter-lm) is the freight rate for transporting a lanemeter of cargo through transport option $i$ and $T T_{i}$ (hours) is the respective travel time, including all waiting times at transit points. $C V(€ / \mathrm{lm})$ represents the cargo value and $r$ is the depreciation rate (\%). Their product is divided by 8760 hours of a year to convert the travel time into $€ / 1 m^{*}$ hour units. This facilitates comparisons among different shipping options, and sensitivity analyses on important parameters (e.g. fuel price, frequency of service, tax levies etc.). In the general case there are $N$ transportation modes available to the shipper. The first split is the decision of the nest $j \in\{M, L\}$ where $M$ is the maritime nest and $L$ the landbased. The probability of choosing nest $j$ is given by equation 2 .

$$
P_{j}=\frac{e^{-\lambda_{1} \cdot G C_{j}}}{\sum_{j=M, L} e^{-\lambda_{1} \cdot G C_{j}}}
$$

Where $\lambda_{1}$ is a dispersion parameter that acts as a weight attached in the choice to the generalized cost. The larger the value of $\lambda_{l}$, the greater the implication of a change in the cost of one option to the decision. Equation 2 introduces $G C_{j}$ known as a composite generalized cost which is a function of the generalized cost of all alternatives within the nest. The second step is the selection of an option within the selected nest; $m$ 
$\in M$ for a maritime option or $l \in L$ for landbased. For example, the probability $\frac{P_{m}}{M}$ of choosing option $\mathrm{m}$ given a maritime nest selection is given by equation 3 .

$$
P_{m / M}=\frac{e^{-\lambda_{M} \cdot G C_{m} / M}}{\sum_{i \in M} e^{-\lambda_{M} \cdot G C_{m} / M}}
$$

where $\lambda_{M}$ is a dispersion parameter for the secondary split within the maritime nest. This can be used to estimate the composite generalized cost of the maritime nest if the generalized cost $G C_{i / M}$ and the respective market shares of each option $\mathrm{i}$ are known. If all the $G C_{i / M}$ are known it is possible to estimate the composite generalized cost $G C_{M}$ (as used in equation 2) through equation 4

$$
G C_{M}=\frac{-1}{\lambda_{M}} \log \left(\sum_{i \in M} e^{-\lambda_{i} \cdot G C_{i} / M}\right)
$$

\subsection{Constructing the dataset}

In case there is only one landbased option and only one maritime option, the model collapses into a binary logit model (choose $M$ or $L$ ). For the calibration of the modal shift model in a baseline case (prior to any changes being introduced) the following steps are necessary:

- List all competing modes

- List origin - destination (O-D) pairs for shipments

- Estimate travel time for each available option

- Retrieve freight rates for each option

- Identify transported cargo for each option

In an ideal scenario, the dataset would contain info on O-D pairs for all cargoes, including information on value of cargo for each shipment, total travel time, and travel cost paid by each shipper. Ro-Ro operators are charging freight rates in terms of $€$ per lanemeter of cargo, and are thus aware of only transported volumes, with typically no information on its value or even weight. Ship operators are usually unaware of the initial origin and final destination of the shipment. The necessary data are summarized in Figure 1 for each transportation mode.

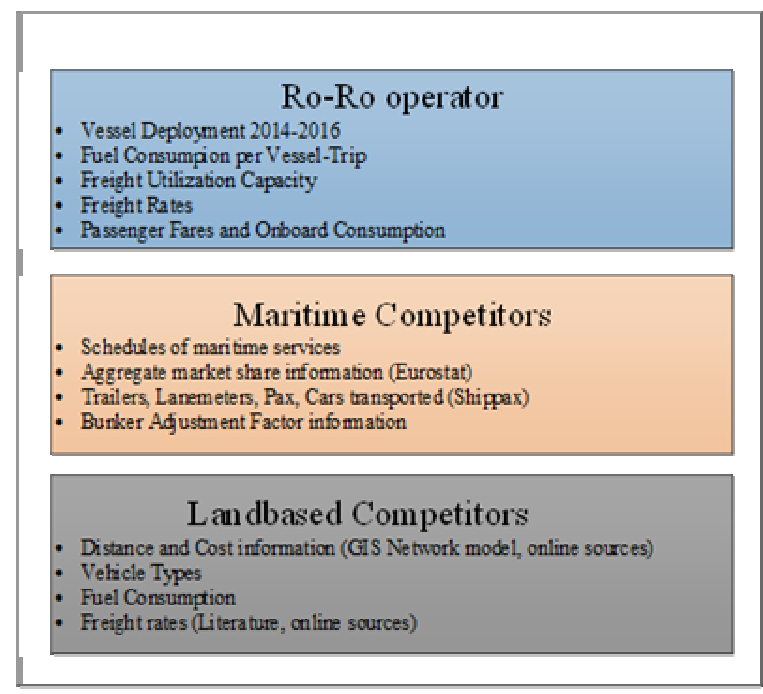

Figure 1: The necessary data for a modal shift model

\subsection{The examined services of a Ro-Ro operator}

Information on a disaggregate level about freight transport flows in the full European road network is currently not available. Data for the period 2014-2016 were provided by a leading European Ro-Ro operator that has routes within SECAs. This paper considers a subset consisting of five services. Table 1 shows the annual percentage change between 2014 and 2015 for the transoported cargo $(\Delta \mathrm{TC}-\mathrm{lm})$, the freight rate $(\Delta \mathrm{FR}-$ $€ / \mathrm{lm})$, revenue $(\Delta \mathrm{RV}-€)$, and fuel cost $(\Delta \mathrm{FC}-€)$.

Table 1: Summary of changes before and after new limit

\begin{tabular}{|c|c|c|c|c|}
\hline Route & $\begin{array}{c}\Delta \mathrm{TC} \\
(\%)\end{array}$ & $\begin{array}{c}\Delta \mathrm{FR} \\
(\%)\end{array}$ & $\begin{array}{c}\Delta \mathrm{RV} \\
(\%)\end{array}$ & $\begin{array}{c}\Delta \mathrm{FC} \\
(\%)\end{array}$ \\
\hline $\begin{array}{c}\text { Gothenburg } \\
\text { Ghent }\end{array}$ & 6.06 & -5.62 & 0.09 & -52.89 \\
\hline $\begin{array}{c}\text { Esbjerg } \\
\text { Immingham }\end{array}$ & 19.46 & -0.5 & 18.85 & -15.29 \\
\hline $\begin{array}{c}\text { Copenhagen } \\
\text { Oslo }\end{array}$ & -5.82 & 1.58 & 4,28 & -9.36 \\
\hline $\begin{array}{c}\text { Klaipeda } \\
\text { Kiel }\end{array}$ & -4.64 & -7.71 & -8.89 & -30.0 \\
\hline $\begin{array}{c}\text { Dover } \\
\text { Calais }\end{array}$ & -17.66 & 9.36 & -18.04 & -50.35 \\
\hline
\end{tabular}

It can be seen that fuel costs have been decreased substantially, while revenue has increased in certain routes, mainly due to the increase in transported cargoes. Table 1 illustrates the unexpectedly outstanding performance of Ro-Ro shipping in 2015, due to the low fuel prices. In four of the routes a binary case is examined (maritime vs landbased option) whereas Gothenburg - Ghent considers a maritime nest, with two seaborne options, and one fully landbased option. This paper is using the calibration results of a recent paper of the authors examining the same network.

A summary of the scale parameter calibration is shown in Table 2, based on previous work of the authors [7]. These values will be used to assess how policy makers and Ro-Ro operators measures can be used to mitigate or reverse the modal shift due to the SECA limit.

Table 2: Scale parameters as adapted from [7]

\begin{tabular}{|c|c|c|c|c|c|}
\hline \multirow{2}{*}{ Route } & \multicolumn{3}{|c|}{$\begin{array}{c}\text { Market Share } \\
\text { (\%) }\end{array}$} & \multicolumn{2}{c|}{$\begin{array}{c}\text { Average scale } \\
\text { parameter }\end{array}$} \\
\cline { 2 - 5 } & RoRo & $\begin{array}{c}\text { Other } \\
\text { Mar }\end{array}$ & Land & $\lambda$ & $\lambda_{\text {mar }}$ \\
\hline $\begin{array}{c}\text { Gothenburg } \\
\text { Ghent }\end{array}$ & $24-30$ & $21-29$ & $39-49$ & 0.027 & 0.025 \\
\hline $\begin{array}{c}\text { Esbjerg } \\
\text { Immingham }\end{array}$ & \multicolumn{2}{|c|}{$60-70$} & $30-40$ & 0.08 & \\
\hline $\begin{array}{c}\text { Copenhagen } \\
\text { Oslo }\end{array}$ & $20-25$ & NA & $75-80$ & 0.108 & \multirow{2}{*}{ NA } \\
\hline $\begin{array}{c}\text { Klaipeda } \\
\text { Kiel }\end{array}$ & $51-61$ & NA & $39-49$ & 0.019 & \\
\hline $\begin{array}{c}\text { Dover } \\
\text { Calais }\end{array}$ & $39-49$ & NA & $51-61$ & 0.015 & \\
\hline
\end{tabular}

\subsection{The KPIs to assess the impacts of interventions}

Rajković et al. (2016) conducted a literature survey on optimization problems in cargo flows using both land and sea legs [8]. They note that in intermodal trans- 
portation the main objectives are typically the minimziation of transportation costs, transit times, and more recently $\mathrm{CO}_{2}$ emissions. The issue of SECA implications on Ro-Ro shipping and reversing any modal shifts towards landbased modes, is addressing these three issues. There may be trade-offs between a less polluting and cheaper transportation (maritime options) vs a faster (landbased options) service. This balance may be illustrated through a formulation of appropriate key performance indicators (KPI).

The potential operators' measures will have effects on the shippers' choices, and on the operating costs of the vessels. This section will present threeKPIsfor the tested measures; profitability (RoRo $\left.o_{\text {prof }}\right)$, utilization $\left(R o R o_{u t i l}\right)$, and emissions intensity $\left(R o R o_{e n v}\right)$.

The profitability of the service depends on various components that provide revenue to the operator, and the different costs that each trip produces. Of particular importance are the effects of the measures on the fuel costs of the vessel at the voyage and at the port. The revenue sources will be affected if there is a change in the transportation demand, and that is where the modal split model will be used. For services that are also carrying passengers there may be a different demand which this paper assumes not to change. With regards to the onboard spending of passengers, this work assumes that this is a function of time; if a voyage is now longer due to a speed reduction the passengers will on average spend more money onboard the vessel (food, drinks, other activities) proportionally to the increased time (for small increases in time). The operator's profitability KPI in this paper is the ratio between the total fuel cost (ports and voyage) over the generated revenue of the service shown in equation 5 .

$$
R o R o_{\text {prof }}=\frac{F R \cdot T U+(P F+P S) \cdot P A X}{F C_{\text {ports }}+F C_{\text {trip }}}
$$

$F R$ is the freight rate $(€ / \mathrm{lm}), T U$ are the transported Units $(\mathrm{lm}), P F$ the passenger fare $(€), P S$ the passenger spending on-board the vessel $(€), P A X$ the number of passengers, $F C_{\text {ports }}$ and $F C_{\text {trip }}$ the fuel costs at port and voyage $(€)$.

The second KPI is reflecting the effect of the measures on the occupancy of the vessels' holds. Following discussions with relevant experts working in the European Ro-Ro sector, a desired utilization rate for the vessel is at $85 \%$ of its nominal capacity that is usually measured in lanemeters of cargo. A higher rate on average may be undesirable as due to fluctuations in demand there may be trips where the vessel cannot satisfy this demand and thus cargoes may not be picked up. A very low utilization rate may result in a non-profitable service. The KPI in this work considers the utilization capacity as the ratio of the transported lanemeters of cargo, over the nominal capacity (NomCap $\mathrm{lm}$ ) of each vessel deployed in a specific service.

$$
R o R o_{u t i l}=\frac{T U}{\text { NomCap }}
$$

The carbon intensity of the transported unit is expressed in grams of $\mathrm{CO}_{2}$ per transported lm-NM.

$$
R o R o_{e n v}=\frac{F C_{i, j} \cdot E F_{C O_{2}}}{T U}
$$

\section{THE EFFICIENCY OF THE APPLIED MEASURES}

This section will present a list of candidate measures for either the ship operator or a policy maker, that can potentially reduce or reverse modal shifts due to the regulation. Their effects on the KPIs will be briefly discussed. A more detailed discussion on the suggested operator's measures can be found in the literature [9].

\subsection{Ro-Ro operator's measures}

Speed reduction is the first measure that will be examined. This may be a viable option should fuel prices increase again.Slow steaming has been very popular in recent years in liner and bulk shipping [10]. When it comes to Ro-Ro shipping there is less flexibility in changing speeds. Ro-Ro services are faster, typically between 16-21 knots, reaching 30-35 for certain Ro-Pax services. Ro-Ro services offer a high number of sailings per week (occasionally even per day) with a sailing typically lasting an integer number of hours (or multiples of 30 minute periods) to facilitate planning the cut-off times at each port for passengers embarkation/disembarkation and cargo loading/unloading operations. This acts as a constraint to the extent of a potential speed changes due to the requirements for the hoteling activities of the vessel. In addition, changing the vessel speed will not only affect the total travel time at sea, but may also have impacts on waiting times at the port thus further increasing the costs for the shipper. Park and Dragovic (2009) provide more information on the modelling of waiting costs and their interrelation with a port's level of operation [11].

The effects of a speed reduction in the fuel consumption were modelled based on data from sea trials of the vessels sailing at different speeds, and consumption data on actual trips in these services. For the new sailing speeds the propeller law was used with an exponent for each vessel that best approximated the sea-trials data (values between 3.2 and 3.6 at the examined speeds). This analysis considers three fuel price scenarios.

- Case 1 (actual fuel prices in 2015): HFO \$260/ton and MGO $\$ 480 /$ ton

- Case 2 (pessimistic scenario): HFO \$530/ton and MGO \$820/ton

- Case 3 (revert regulation): use HFO at \$260/ton

A summary of the effects of a speed change on the KPIs is shown in Figure 2, considering the three fuel price scenarios.

The analysis is performed on three tiers of speed changes. In tier 1 , we consider a 1 hour increase in Gothenburg -Ghent, a 0.5 in all other routes. The second Tier 2 examines a 2 hour increase in Gothenburg Ghent and a 1 hour in other routes. The final Tier 3 is analysing the effects a 3 hour increase in Gothenburg Ghent would have, along with a $1.5 \mathrm{hr}$ increase in Esbjerg - Immingham while the other routes are not considering a third potential speed change. 
Fnet Case 1
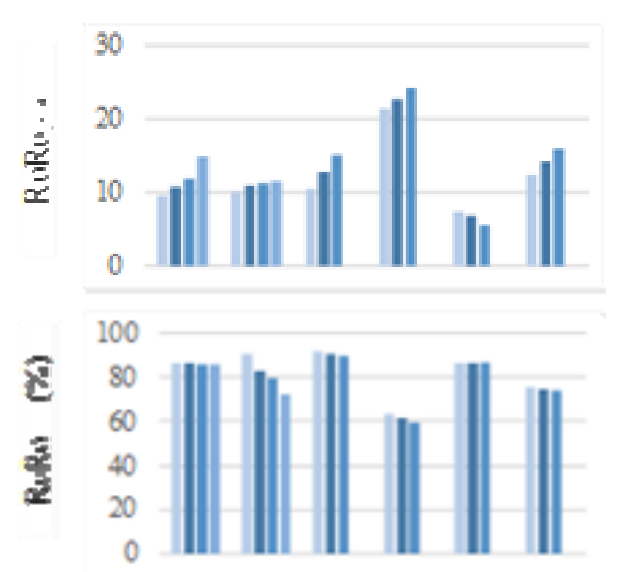

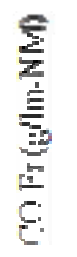

400

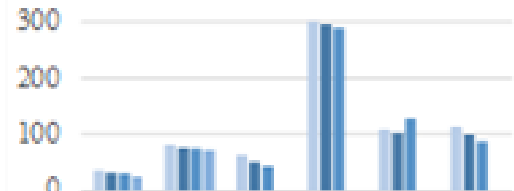

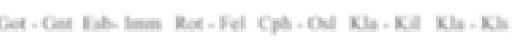
$=$ Baseline $=$ Tier $1=$ Tier 2 =Tier 3
Fnel Case 2

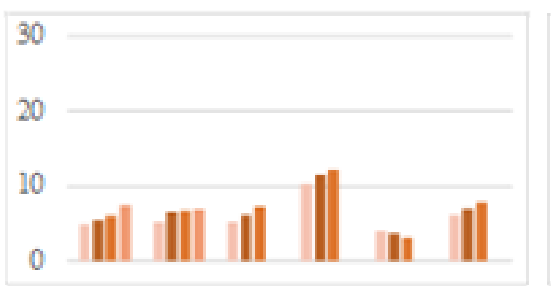

100

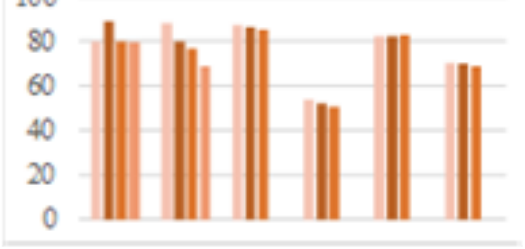

400

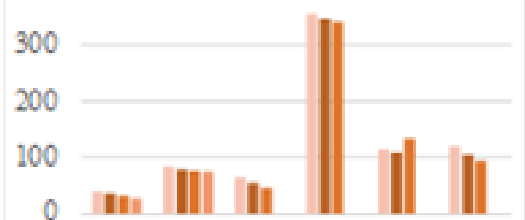

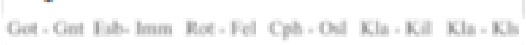
m Baseline aTier 1 aTier 2 =Tier 3
Fual Cose 3
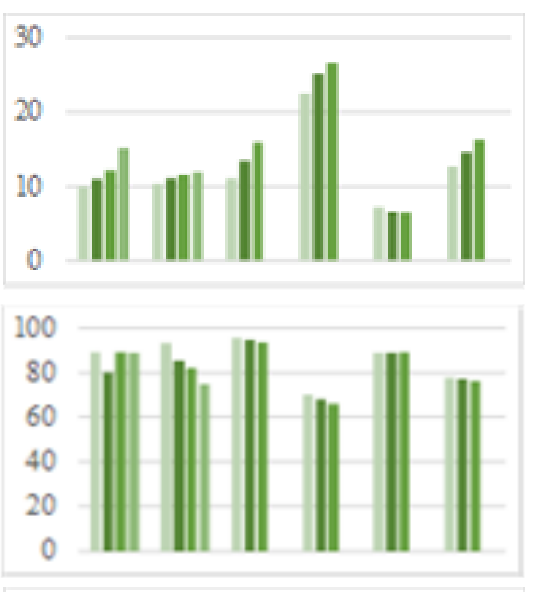

400

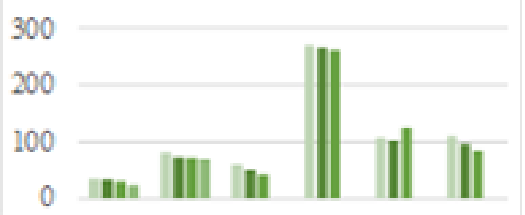

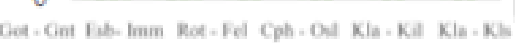

= Baseline $\mid$ Tier 1 -Tier 2 |Tier 3

\section{Figure 2: Effects of Speed Changes to the examined KPIs}

The results of the changes in speed on the established KPIs can help draw a conclusion on the effectiveness of the measure in different fuel price scenarios. What can be observed from Figure 2 is that if fuel prices increase again, there is a significant drop in the $R o R o_{\text {prof }}$, and a speed reduction can be important in salvaging the situation. The effects of the use of MGO are shown if the blue and green charts are compared. It is evident that if the regulation was not forced, the RoRo $o_{\text {prof }}$ would be slightly higher. For the $R o R o_{u t i l}$, it is shown that there will be some changes for the different fuel prices. For $R o R o_{e n v}$, it is evident that the speed reduction will result in all cases in improved performance. For Klaipeda - Kiel, an increased sailing speed scenario was examined (Tier 2), as in 2016 the service has sped up by 2 knots. It should also be noted that the very high $R_{0} R_{e n v}$ in the Ro-Pax vessels is under the assumption that all emissions are allocated to the transported cargoes, which is not realistic.

The second operators' measure is consdering a change in the sailing frequency of a service. This measure is examined for fuel prices in all fuel case scenarios, where in the Case 1 and 2 there is a small reduction in the sailing frequency, and a higher frequency for Case 3 (allowed use of HFO at 2015 price levels)due to increased demand. This measure is considered for three services where it is easily applicable, with no requirement for changing the number of deployed vessels. Table 3 provides a summary of results for a few scenarios.

Table 3 shows that a reduction in the sailing frequency for high fuel prices would lead to significant increases in the utilization factor of the vessels, to a point where it would be undesirable. This is due to the assumption that the reduction would result in a small drop in transportation demand, as the service that would be cancelled would be the second service of the weekend. For the cases where a change in frequency would lead to a better $R o R O_{\text {prof }}$ the ship operator would have to also consider the change in other operating costs (e.g. port fees, staff costs, depreciation) before altering the frequency.

Table 3: Effects of a new sailing frequency

\begin{tabular}{|c|c|c|c|c|}
\hline Fuel prices & New frequency & $\begin{array}{c}\text { RoRo }_{\text {util }} \\
(\%)\end{array}$ & $\begin{array}{r}\Delta \mathrm{R} \\
(€)\end{array}$ & $\begin{array}{c}\Delta \mathrm{FC} \\
(€)\end{array}$ \\
\hline \multicolumn{5}{|c|}{ Esbjerg - Immingham (baseline 6 sailings per week) } \\
\hline Case 2 & 5 & 96.6 & -112000 & -33500 \\
\hline Case 3 & 7 & 82.02 & 40000 & 16600 \\
\hline \multicolumn{5}{|c|}{ Klaipeda - Kiel (baseline 7 sailings per week) } \\
\hline Case 1 & 6 & 97.36 & -32400 & -28170 \\
\hline Case 2 & 6 & 96.19 & -25080 & -57090 \\
\hline \multicolumn{5}{|c|}{ Dover - Calais (baseline 99 sailings per week) } \\
\hline Case 1 & 75 & 94.63 & -56000 & -58900 \\
\hline Case 2 & 75 & 88.25 & -74600 & -119300 \\
\hline
\end{tabular}

The third operators' measure presented in this work is considering swapping vessels between compatible services. A summary of results is shown in Table 4 for two routes.

Table 4: Effects of vessel swapping

\begin{tabular}{|c|c|c|c|c|}
\hline Route & \multicolumn{2}{|c|}{ Gothenburg Ghent } & \multicolumn{2}{c|}{ Esbjerg Immingham } \\
\hline Fuel prices & RoRo $_{\text {util }}$ & $\mathbf{\Delta F C ~ ( € )}$ & RoRo $_{\text {util }}$ & $\begin{array}{c}\Delta \text { FC } \\
(\boldsymbol{€})\end{array}$ \\
\hline Case1 & 92.08 & -4660 & 94.32 & -11000 \\
\hline Case 2 & 85.49 & -9500 & 91.45 & -22400 \\
\hline Case 3 & 95.36 & -4500 & 96.59 & -10711 \\
\hline
\end{tabular}

For Gothenburg - Ghent the fuel benefit is very small for the low fuel price scenarios. The swap is considered with a smaller vessel currently sailing in a different service of the operator (Gothenburg - Immingham), and 
it would be meaningful if this service increased its demand.For Esbjerg - Immingham the fuel savings can be important at high fuel prices as a more fuel-efficient vessel is moved from a less frequent service.

The final measure that is examined in this work is considering the installation of a scrubber system in one of the non-retrofitted vessels of the operator. The vessel with the highest fuel consumption was selected for this case study. Using an estimated retrofit cost of $€ 250$ per $\mathrm{kW}$ of installed main engine power, the capital cost of investment would be in the region of approximately $4.8 \mathrm{M} €$. The total weekly fuel consumption for the vessel reaches 303 tons. Following an installation of scrubbers, the additional fuel consumption is assumed to be $3 \%$ to cover the scrubber's energy requirements [6]. The operating cost savings will depend on the fuel price differential of HFO and MGO. At the highest fuel prices observed in the two years between 2014 and 2015, the investment in scrubber systems would seem as very promising. However, taking into account the lowest fuel prices observed in the end of 2015, the payback period increases to 4.3 years e.g. 2020. At that point in time, the global sulphur cap will be enforced and potentially new technologies would be available that would constitute investing in scrubbers in 2016 less appealing. Considering these simplistic calculations, the age of the vessel should also be taken into account as if a vessel has less than 5 years of remaining service, investing in scrubbers may not make sense.

\subsection{Policy measures}

The first measure assumes that a policy body will cover the additional surcharges that are passed on to shippers through the Bunker Adjustment Factor (BAF) and due to the low sulphur limit. The exact value of BAF depends on various service characteristics, including length, frequency, sailing speed, and ship type. In this work, the BAF policy of the ship operator providing most of the data is used. The annual costs for the policy body are shown in table 5 .

Table 5: Impacts of subsidizing the BAF surcharges

\begin{tabular}{|l|c|c|c|c|c|c|c|c|}
\hline \multicolumn{1}{|c|}{ Route } & \multicolumn{2}{|c|}{$\begin{array}{c}\text { Goth } \\
\text { Ghent }\end{array}$} & \multicolumn{2}{c|}{$\begin{array}{c}\text { Esbj } \\
\text { Imm }\end{array}$} & \multicolumn{2}{c|}{$\begin{array}{c}\text { Klai } \\
\text { Kiel }\end{array}$} & \multicolumn{2}{c|}{$\begin{array}{c}\text { Dov } \\
\text { Cals }\end{array}$} \\
\hline Fuel Case & 1 & 2 & 1 & 2 & 1 & 2 & 1 & 2 \\
\hline BAF $(€ / 1 \mathrm{~m})$ & 1.37 & 5.13 & 1.19 & 4.3 & 1.76 & 6.34 & 0.33 & 1.2 \\
\hline Cost $(\mathrm{M} €)$ & 2.5 & 10.1 & 1.96 & 7.82 & 2.27 & 8.48 & 2.35 & 9.0 \\
\hline RoRo $_{\text {util }}$ & \multicolumn{2}{|c|}{$+2.5 \%$} & \multicolumn{2}{c|}{$+3.5 \%$} & $+1.43 \%$ & $+1.6 \%$ \\
\hline
\end{tabular}

If the fuel prices were as high as in early 2014, then the policy would cost approximately 4 times more for each route. The lower costs in Case 1 essentially represent the effects of the SECA limit on the shippers using this service. If the BAF was paid back to the shippers, then the services would have increased their market share, and also the utilized capacity of the deployed vessels as shown from $R o R o_{u t i l}$. .However, a uniform policy to refund the shippers using the maritime mode shows that it will be very costly, considering that that the annual policy costs shown in Table 5 are for a single service, and there are many more affected services.

The second policy measure to be considered is the introduction of an additional landbased tax levy, that would demotivate modal shifts from SSS. An explanatory analysis is conducted where the objective is to identify what percentage increase in the total monetary cost of landbased transport options will result in absorbing the modal backshift attributed to the low sulphur fuel requirement. The necessary percentage increases are summarized in Table 6, for the two fuel price scenarios.

Table 6: Tax levy to reverse modal splits due to SECA

\begin{tabular}{|l|l|l|}
\hline Route & Fuel Case 1 & Fuel Case 2 \\
\hline Gothenburg Ghent & 3.83 & 14.48 \\
\hline Esbjerg Immingham & 2.48 & 8.95 \\
\hline Copenhagen Oslo & 7.15 & 25.8 \\
\hline Klaipeda Kiel & 3.52 & 12.68 \\
\hline Dover Calais & 2.12 & 7.74 \\
\hline
\end{tabular}

Table 6 shows that the examined Ro-Ro services would be at considerable risk for high fuel prices. The necessary increase in the landbased option to offset the effects of the higher BAF is increasing significantly in FC2. The wide variance of the necessary landbased tax levy is evidence of the sensitivity of the total road lengths in the shippers' decision making process. Therefore, suggesting a flat levy at $10 \%$ (e.g. in the form of an additional tax on petrol) would lead to net modal shifts towards maritime services for most routes). The third policy measure considers the costs of providing subsidies towards ship operators to retrofit their vessels with relevant abatement technology (e.g. scrubber systems). The previous policy measures considered annual costs, but it may be better to provide a subsidy to operators towards abatement investments. In the recent past, the European Commission provided subsidies of $20 \%$ for the retrofitting of vessels, with indicative costs of 1.5 M€ per vessel. The assumption of this measure is that a policy body would cover $20 \%$ of the required investment costs for each retrofit. This analysis is only conducted to compare the total costs with the previously examined measures. The actual costs of a retrofit were taken based on published estimates as a function of total installed power $(250 € / \mathrm{kW})$. The costs are summarized in table 7 .

Table 6: Retrofit subsidy requirements

\begin{tabular}{|l|c|c|}
\hline \multicolumn{1}{|c|}{ Route } & $\begin{array}{c}\text { Number } \\
\text { of deployed Vessels }\end{array}$ & $\begin{array}{c}\text { Retrofit } \\
\text { subsidy (M€) }\end{array}$ \\
\hline $\begin{array}{l}\text { Gothenburg } \\
\text { Ghent }\end{array}$ & 3 & 6 \\
\hline $\begin{array}{l}\text { Esbjerg } \\
\text { Immingham }\end{array}$ & 2 & 3.9 \\
\hline $\begin{array}{l}\text { Copenhagen } \\
\text { Oslo }\end{array}$ & 2 & 4.7 \\
\hline $\begin{array}{l}\text { Klaipeda } \\
\text { Kiel }\end{array}$ & 2 & 4.8 \\
\hline Dover Calais & 2 & 4.4 \\
\hline
\end{tabular}

It can be seen that such a policy would require significant funds for the installation of scrubbers on all the available vessels. However, these costs are one-off (unlike other policies that could be annual) and in theory could be combined with a requirement that the benefitted ship operators would reduce the BAF surcharge since they could still use HFO. 


\section{CONCLUSIONS AND FURTHER WORK}

This paper proposed a series of operational measures tailored for Ro-Ro services operating within SECAs, These were examined with regards to their effects on shippers choice, using an existing modelling framework that estimates modal shifts as a consequence of changes in the generalized cost of transport in any of the available options. The measures considered changes in the sailing speed of the vessels for various fuel case scenarios, a new weekly sailing frequency, or a simple fleet reconfiguration to take advantage of the variations in the carrying capacity of the vessels. The efficacy for the measures was examined through three KPIs that reflect the profitability of a service, its carbon footprint, and the utilized capacity of each vessel.

Reduced sailing speeds are suggested for high fuel prices, as there are minimal cargo losses and significant fuel savings. However, there are limitations on how much a speed can be reduced, as this will lead to reduced times at port and there must be enough time to guarantee smooth loading/unloading operations. Adaptations in the sailing frequency of the services were also tested, and it was shown that the fuel savings are higher than the loss of revenue for high fuel prices. Changes in the sailing frequency have important effects on the utilization rate of each vessel, and the operator can alter the frequency as a coping mechanism when the utilization factor is very high (risk of transport demand exceeding the capacity of the vessel) or very low (poor performance environmentally and financially). Swapping vessels between compatible services was also considered, under the assumption that the schedule of each service would not be altered, and thus there would be no change in the shippers' choice. This measure is also promising in terms of optimizing the capacity load factor of each vessel. The paper also considered the option of further investments in abatement technologies such as scrubbers, but the timing is not optimal due to the current low fuel prices and the uncertainty on fuel costs with the upcoming global sulfur cap. Finally, the paper compared the costs of subsidising the shippers using a Ro-Ro service, by paying back the additional BAF surcharges. This would increase the market share of each option significantly but at very high annual costs for each service. These costs are comparable to a one-off subsidy to the ship operators for abatement technology investments.

The overall conclusion of this paper is that selecting the right measure can prove critical in ensuring the viability of a Ro-Ro service that strongly competes with landbased modes. The developed KPIs and the presented methodology can assist ship operators in deciding which measure is preferable of each service. The modelling framework can also be useful to policy makers seeking to understand the effects of new regulation on the shipping sector, as well as to estimate the monetary costs to reverse the negative effects of otherwise successful environmental regulations.

Additional research is required in this field particularly with the current trends of fuel prices that have started to increase to previous higher levels. What occurred in 2015 can be regarded as an unexpected fortunate coincidence that greatly relieved the pressure SSS operators were preparing for before the SECA limits. At the same time, the fact that the global sulphur cap is coming from January $1^{\text {st }} 2020$, it is evident that more disruptions can be expected in the maritime shipping sector. More reliable fuel price predictions are necessary to comprehend the ffects of the global cap, and the reduced low-sulphur fuel availability. Ro-Ro services that are currently unaffected by the SECA limits will also be hindered vulnerable to potential modal shifts.

As this research has shown, data quality is vital for a refined prediction of modal shifts and for the development of contingency plans for both ship operators and policy makers. Data on disaggregate level may not always be accessible to transport planners due to the competitive nature of the sector. However, information sharing between shippers and ship operators can help the latter to deploy better pricing policies and ensure that cargoes are not lost to other modes. After all, the European Union has set a target to achieve a modal shift from landbased options towards maritime ones, and a similar goal has been contemplated in other parts of the world. Finally, a potential internilization of external costs is also a measure that requires further investigation, considering the potential induction of shipping the European Emissions Trading Scheme (ETS) as of 2023.

\section{ACKNOWLEDGMENT}

The work presented in this paper is in the context of the project: "Mitigating and reversing the side-effects of environmental legislation on Ro-Ro shipping in Northern Europe" funded by the Danish Maritime Fund.

\section{REFERENCES}

[1] United Nations Conference on Trade and Development: Review of maritime transport. UNCTAD /RMT/2016, United Nations publication, 2016. http:/unctad.org/en/PublicationsLibrary/rmt2016_e n.pdf, accessed June 2017.

[2] Bjornland, D.: The importance of short sea shipping in European Transport. ECTM, Short Sea Shipping, Economic Research Center, 1993.

[3] IMO: Third IMO GHG Study 2014. International Maritime Organization (IMO), London, 2014.

[4] Eyring V. et al.: Emissions from international shipping: The last 50 years. Journal of Geophysical Research: Atmospheres, 110(D17), 2005.

[5] Danish Maritime Authority: A feasibility study for an LNG filling station infrastructure and test of recommendations. North European LNG Infrastructure Project, 2012.

[6] Zis, T., Angeloudis, P., Bell, M. G., Psaraftis, H. N.: Payback period for emissions abatement alternatives: The role of regulation and fuel prices. In Transportation Research Record (In-press), 2016.

[7] Zis, T., Psaraftis, H. N.: The implications of the new sulphur limits on the European Ro-Ro sector. Transportation Research Part D: Transport and Environment, Vol. 52, pp. 185-201, 2017. 
[8] Rajković, R. Z., Zrnić, N. Đ., Kirin, S. D. and Dragović, B. M.: A review of multi-objective optimization of container flow using sea and land legs together,FME Transactions, Vol. 44, No. 2, pp. 204-211, 2016.

[9] Zis, T. and Psaraftis, H. N.: Operational measures to mitigate and reverse the potentialmodal shifts due to environmental legislation. Maritime Policy \& Management (in press), 2018.

[10] Psaraftis, H. N. and Kontovas, C. A.:Balancing the economic and environmental performance of maritime transportation. Transportation Research Part D: Transport and Environment, Vol. 15, No. 8, pp. 458-462, 2010.

[11] Park, N. K. and Dragović, B.: A study of container terminal planning,FME Transactions, Vol. 37, No. 4, pp. 203-209, 2009.

\section{КљУЧНИ ИНДИКАТОРИ УЧИНКА ЗА ПРОЦЕНУ И ПРОМЕНУ НЕГАТИВНОГ УТИЦАЈА SЕСА ПОЛИТИКЕ НА РО-РО БРОДОВЕ}

\section{Т. Зис, Х.Н. Псарафтис}

Гранична вредност сумпора од $0,1 \%$ у оквиру подручја надзора емисије сумпора (SECA) наметнула је обавезну употребу скупљег горива са изузетно малим процентом сумпора или инсталирање технологија за редукцију емисије сумпора што тражи значајна улагања капитала. Због неочекивано ниских цена горива, Ро-Ро бродски превозници су могли да се изборе са новим граничним вредностима емисије сумпора. Међутим, најновија истраживања показују да ће, уколико цене горива наставе да расту, неке Ро-Ро услуге бити обустављене. У раду се предлажу три кључна индикатора учинка за процену утицаја SECA на РоРо бродове. Индикатори су примењени на низ студија случајева везаних за услуге водећих европских Ро-Ро оператора и извршена је упоредна процена низа оперативних мера и политике које имају за циљ да промене негативан утицај SECA политике. Оперативне мере укључују смањење брзине, нову фреквентност пловидбе, реконфигурисање флоте, као и инвестиције у технологије за редукцију емисије сумпора. Мере политике обухватају опције субвенција бродским превозни-цима или шпедитерима, или увођење нових пореза према опцијама везаним за копно. Од индикатора могу имати користи бродски превозници који теже повећању флексибилности пловне мреже као и регулаторна тела која пројектују нову политику заштите животне средине и разумеју све негативне импликације које она може имати по бродске превознике. 